\title{
Impacts of Sports Facilities Development on Environmental in Semarang City: Case Study in Tri Lomba Juang Sports Arena
}

\author{
Tandiyo Rahayu ${ }^{1(*)}$, A R Sulastrio ${ }^{1}$, B Castyana $^{1}$ \\ ${ }^{1}$ Faculty of Sports Science, Universitas Negeri Semarang, Indonesia 50229 \\ "Corresponding author.Email: tandiyorahayu@mail.unnes.ac.id
}

\begin{abstract}
This descriptive study aims to know further about the impact of the sports facilities construction towards both for users and communities who live around the arena. 20 samples derived from people who live around the arena, and are within 50 meters, 50 samples derived accidently from ordinary people who use the sports facilities in Tri Lomba Juang. 64 items of questionnaire used to describe 4 factors, which are ecology, health, sociocultural, and economics. The results showed, $40 \%$ participants answered that the quality of the environment is disrupted by the construction and the use of sports facilities. Only $36 \%$ said, the availability of access to sports facilities has an impact on the quality of health. $48 \%$ of participant states that the existence of sports facilities and activities in their neighbourhood give a positive impact on social interaction and communication. And $48 \%$ said that the activities in the sports facilities are markets that provide economic benefits. It can be concluded that the existence of the sports arena in the middle of the settlement is less beneficial for the environment and does not directly impact the health quality of the surrounding community, but beneficial for the establishment of social interaction and economic improvement.
\end{abstract}

Keywords: Sports facilities, environmental, development

\section{INTRODUCTION}

The existence of sports arena that meets the international standards, is one of a kind indicator of a modern city, because, these days, sport is everyone's need [1]. To carry out sports activities, it is very necessary to provide sports facilities that meet the standards, both in quality and quantity, which can be easily accessed by the public. Currently, Semarang city is trying to become "an athletes' city", and it is important to provide adequate sports facilities. The development of sports facilities in Semarang, at present, has been arranged in a long-term plan based on the direction of policies and strategies for developing sports areas which include [2]:

- Revitalization of Jatidiri Sports Center in Gajahmungkur District

- Revitalizing the Citarum Stadium in East Semarang District;

- Revitalization of the Tri Lomba Juang Sports Arena in Central Semarang District

- Revitalization of Diponegoro Stadium in Central Semarang District

- Revitalization of Manunggal Jati Sports Center in Pedurungan District

- Sports Center Construction in Pedurungan District

- Sports Center Construction in Mijen District
The construction of this sports facility also occurred because of the rapid population growth in Semarang [3].

One part of the plan that has been determined by the Semarang City government is revitalization of Tri Lomba Juang Sport Arena. Tri Lomba Juang is a very strategic sports arena, because it is located in the middle of the city and stand among the settlement, making it easily accessible to all groups and communities. It has undergone total renovation and revitalization. The sports facilities, especially those located in the middle of settlements, can be beneficial because it is easy to be accessed by the community, but at the same time causes detrimental effect to environmental. This study aims to know further about the impact of the sports facilities construction towards both for users and communities who live around the arena. Because the United Nations Environmental Program (UNEP) has explained that sports actually have an impact on the environment as a result of the construction and maintenance of sports facilities [4]. Some of the impacts on the environment include:

- Noise and light pollution

- The use of non-renewable materials, such as fuel, the use of metal for building frames, etc.

- Excessive use of natural resources 
- The higher greenhouse effect results from the use of electricity and fuel

- Soil and water pollution from pesticide use for swimming pool

- The emergence of soil erosion as a result of the construction and the weight borne when the sports facility is visited by the spectator

- Waste arising during construction and when using sports facilities

\section{METHOD}

This descriptive study utilized survey method for getting the data with 4-points likert questionnaire. The sample was 20 respondents derived from people who live around the arena, and are within 50 meters, 50 samples derived accidently from ordinary people who use the sports facilities in Tri Lomba Juang with snowball sampling technique. There were 64 items of questionnaire used to describe 4 factors, which are ecology, health, sociocultural, and economics. Finally, after all the data was taken, it was analyzed using percentage with frequency distribution technique.

\section{RESULT AND DISCUSSION}

The results showed, $40 \%$ participants answered that the quality of the environment is disrupted by the construction and the use of sports facilities. Only 36\% said, the availability of access to sports facilities has an impact on the quality of health. $48 \%$ of participant states that the existence of sports facilities and activities in their neighbourhood give a positive impact on social interaction and communication. And $48 \%$ said that the activities in the sports facilities are markets that provide economic benefits.

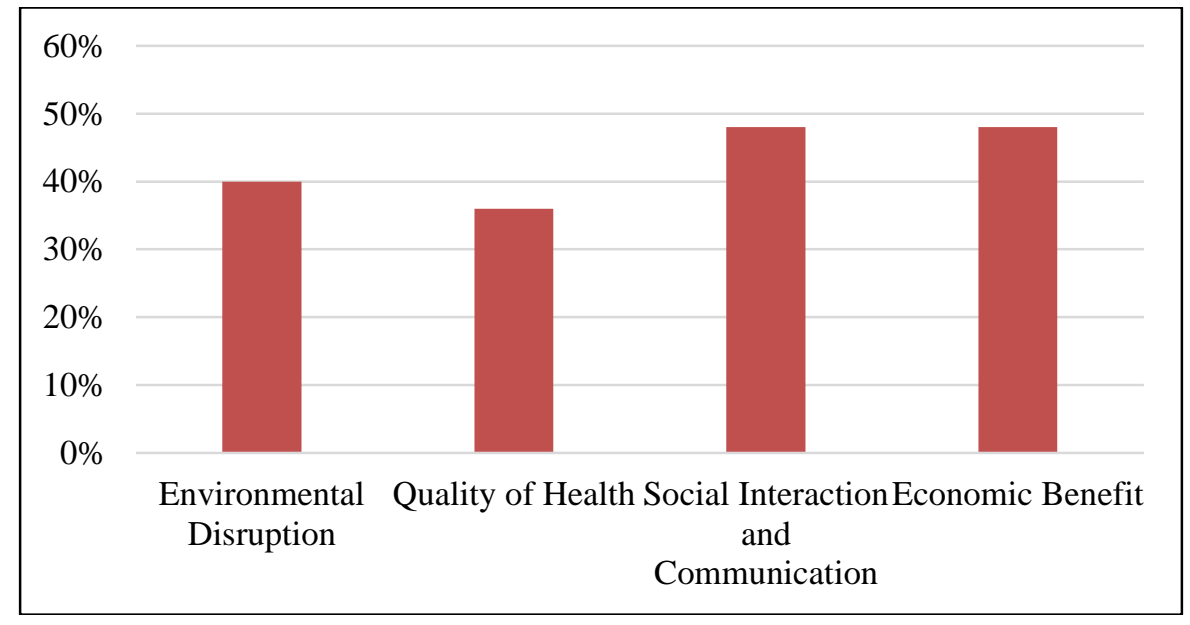

Figure 1. Environmental Impact on Sport Facilities Construction and Utilizing

\section{Quality of Environment}

Based on the results about environmental disruption shown above, it means, there is pressure on the environment and now require quick solutions, including how to maintain sustainability. One solution that can be done is to start the Environmental Sustainability movement. However, the research [5] shows that the lack of financial support for environmental sustainability based construction is the biggest obstacle. That is why, the role for the government in implementing these changes is really needed [6]. The government is expected to overcome the challenges faced by environmental sustainability based development, through policy making, supervision and implementation in the field [5], including working with investors to support financially [7]. In addition, environmental sustainability can also be carried out by sports organizations that use these sports facilities, because they can make efficient use of budgets for maintenance and operations [8]. However, the government and sports organizations cannot work alone, the community must also participate in this movement. If people are apathetic and show an attitude of uncertainty that environmental changes can occur, then this will be the biggest challenge in realizing environmental sustainability [9]. Because, apathy and negative attitudes from the community will make a failure in the process [10]. Therefore, if these challenges and obstacles are not taken seriously and sustainably, environmental disruption will continue along with the construction of sports facilities.

\section{Quality of Health and Social Interaction}

Apart from environmental disruption that arises as a result of the construction of sports facilities, Sports facilities have two main functions in urban life, as a means of recreation and environmental binding [11]. Those main functions also have a positive impact to improve the quality of health of local residents, such as improving physical well-being, improving social wellbeing, and improving mental well-being [12]. Those improvements could be done by improving the social 
interaction among community nearby. According to the result, community agree if the existence of Tri Lomba Juang improve the social interaction among them, however the social interaction is not the only factor which can measure the improvement of health quality. Because, after the revitalization carried out at Tri Lomba Juang, the surrounding community did not feel the direct impact of health quality improvement. This can occur as a result of a lack of community desire for physical activity.

Research conducted in the last few years show that there are various characteristics that affect a person's desire for physical activity, one of it is the environment [13]. Because the environment must be built and the development of this environment, in the future, can influence and motivate people to have an active lifestyle [14]. Based on this, there are three environmental factors that can make people physically active, namely accessibility, appeal, and security [15]. When viewed from the accessibility factor, Tri Lomba Juang are in the middle of housing located in the city centre. So that this facility has good access. Moreover, public transportation also passes around it a lot.

Tri Lomba Juang, which was built at a cost almost 2 million dollars, also has its own appeal. The public also often take pictures in sports areas that have several venues, such as tennis, badminton and athletic fields. However, an attractive building design has not been a benchmark whether people come there for physical activity or just for recreation. One thing that must be considered when building a sports facility is the compatibility between the facilities built with the demographics of the surrounding community and the needs of the community [16]. If there are many young people around the area, then the development must be adjusted to what kind of sports they are interested in. Development also needs to prioritize its usefulness for the surrounding community. Because, if sports facilities are more widely used for activities that involve many people outside the surrounding environment, it will make the local residents also less interested in activities there [17]. Because sports facilities are not only used for physical activity but also to meet with local residents.

The last factor that can make people want to do physical activity in sports facilities is security. When people are physically active, they want to be sure that the vehicles they park and the goods they carry will be safe. This is also related to measuring the success of a city [13]. Security also talks about supporting facilities, such as lighting, cleanliness, and the level of crowd from the surrounding environment. These are points that must be considered as well [13]. These three factors indicate that sports facilities should be built not only as an obligation of a city to provide it. However, the government and stakeholders must be able to make the community around sports facilities want to continue physical activity there so that the quality of their health also improves.

\section{Economic Benefit}

Currently, Semarang is undergoing massive construction and renovation of sports facilities. This also relates to economic impacts, such as increasing income from trading around sports facilities, creating new jobs, and paying taxes from using sports facilities [18]. The results of data processing also show that the community felt the impact of the construction of sports facilities economically. One effect that is felt is the increase in property values around sports facilities [19]. In addition, rental values from shophouses and buildings that will function as amenities around sports facilities also increase due to increased use of sports facilities, both during activities and on weekdays.

\section{CONCLUSION}

It can be concluded that the existence of the sports arena in the middle of the settlement is less beneficial for the environment and does not directly impact the health quality of the surrounding community, but beneficial for the establishment of social interaction and economic improvement. Seeing from the discussion above, the government and developers of sports facilities must begin to pay attention that the construction of sports facilities is not just beautifying and rejuvenating the building. Stakeholders must be able to understand the needs and impacts that will occur in the long run. In addition, further research is needed on the impact of the environment on the construction of other sports facilities in Semarang.

\section{REFERENCES}

[1] Santosa I, Sugiyanto S, Kristiyanto A. Kebijakan Pemerintah Tentang Penyediaan Sarana dan Prasarana Olahraga Publik di Kabupaten Kudus (Studi Evaluasi Tentang Perencanaan, Ketersediaan, Pemanfaatan, dan Pengelolaan Sarana dan Prasarana Olahraga). Indonesian Journal of Sports Science. 2014 Jul 6;1(1).

[2] Perdana F. Gedung Persatuan Bulutangkis semarang. Imaji. 2014 jul 1;3(3):199-208.

[3] Ardiansyah r, malik a, rukayah s. Revitalisasi gelanggang olahraga trilomba juang sebagai taman olahraga kota semarang (Doctoral dissertation, Universitas Diponegoro).

[4] Mallen C, Chard C. "What could be" in Canadian sport facility environmental sustainability. Sport Management Review. 2012 May 1;15(2):230-43.

[5] Mallen C, Adams L, Stevens J, Thompson L. Environmental sustainability in sport facility management: A Delphi study. European Sport 
Management Quarterly. 2010 Jun 1;10(3):36789.

[6] Trendafilova S, McCullough B, Pfahl M, Nguyen SN, Casper J, Picariello M. Environmental sustainability in sport: Current state and future trends. Global Journal on Advances Pure and Applied Sciences. 2014;3:914.

[7] Juravle C, Lewis A. The role of championship in the mainstreaming of Sustainable Investment (SI) what can we learn from SI pioneers in the United Kingdom?. Organization \& Environment. 2009 Mar;22(1):75-98.

[8] Sharma S. The mediating effect of information availability between organization design variables and environmental practices in the Canadian hotel industry. Business Strategy and the Environment. 2009 May;18(4):266-76.

[9] Trendafilova S, Kellison TB, Spearman L. Environmental sustainability in sport facilities in East Tennessee. Journal of Facility Planning, Design, and Management. 2014;2(1).

[10] Quimby CC, Angelique H. Identifying barriers and catalysts to fostering pro-environmental behavior: Opportunities and challenges for community psychology. American Journal of Community Psychology. 2011 Jun 1;47(34):388-96.

[11] Rarasati BD. Kesenjangan antara Permintaan dan Penyediaan Fasilitas Olahraga di Kota Bandung. Journal of Regional and City Planning. 2010 Aug 1;21(2):147-64.

[12] Pakzad P, Osmond P. Developing a sustainability indicator set for measuring green infrastructure performance. Procedia-social and behavioral sciences. 2016 Jan 6;216:68-79.

[13] Roult R, Adjizian JM, Lefebvre S, Lapierre L. The mobilizing effects and health benefits of proximity sport facilities: urban and environmental analysis of the Bleu, Blanc, Bouge project and Montreal North's outdoor rink. Sport in Society. 2014 Jan 2;17(1):68-88.

[14] Sallis JF, Bowles HR, Bauman A, Ainsworth BE, Bull FC, Craig CL, Sjöström M, De Bourdeaudhuij I, Lefevre J, Matsudo V, Matsudo S. Neighborhood environments and physical activity among adults in 11 countries. American journal of preventive medicine. 2009 Jun 1;36(6):484-90.

[15] Brownson RC, Hoehner CM, Day K, Forsyth A, Sallis JF. Measuring the built environment for physical activity: state of the science. American journal of preventive medicine. $2009 \mathrm{Apr}$ 1;36(4):S99-123.

[16] Reis RS, Hino AA, Florindo AA, Añez CR, Domingues MR. Association between physical activity in parks and perceived environment: a study with adolescents. Journal of Physical Activity and Health. 2009 Jul 1;6(4):503-9.

[17] Lefebvre S, Roult R, Adjizian JM, Lapierre L. Planning and social appropriation of proximal sports facilities: the case of the exterior skating rink project 'Bleu Blanc Bouge'in Montreal North. Loisir et Société/Society and Leisure. 2014 Jan 2;37(1):101-15.

[18] Feng X, Humphreys B. Assessing the economic impact of sports facilities on residential property values: A spatial hedonic approach. Journal of Sports Economics. 2018 Feb;19(2):188-210.

[19] Ahlfeldt GM, Kavetsos G. Form or function?: the effect of new sports stadia on property prices in London. Journal of the Royal Statistical Society: series A (statistics in society). 2014 Jan;177(1):169-90. 